\title{
PARÓDIA E DESLOCAMENTO DE SENTIDOS: A TROPA DE NHOQUE ENTRA EM CENA
}

\section{PARODY AND DISPLACEMENT OF MEANINGS: SEND IN THE TROPA DE NHOQUE}

\author{
Suzy Lagazzi \\ Universidade Estadual de Campinas, Unicamp, Campinas, SP, Brasil \\ Romulo Santana Osthues ${ }^{1}$ \\ Universidade Estadual de Campinas, Unicamp, Campinas, SP, Brasil \\ Flavio da Rocha Benayon ${ }^{2}$ \\ Universidade Estadual de Campinas, Unicamp, Campinas, SP, Brasil
}

Resumo: A partir da análise de vídeos que documentam atuaçóes das Tropas de Nhoque, procuramos compreender o funcionamento da paródia - em particular, frente aos Aparelhos Repressivos de Estado - como mecanismo que possibilita o deslocamento de sentidos. Os grupos denominados Tropas de Nhoque compóem performances cênicas nas quais são utilizados narizes de palhaço, escudos de papelão (com a inscrição NHOQUE) e armas de brinquedo, entre outros artefatos, satirizando as violentas operaçôes dos batalhōes de choque das polícias militares em confrontos com manifestantes. Os episódios analisados ocorreram nas ruas do Rio de Janeiro e de Porto Alegre, em julho e setembro de 2013.

Palavras-chave: Protestos; Paródia; Performance tática; Palhaço; Tropa de Nhoque.

Abstract: Based on the analysis of videos that document the performances of the Tropas de Nhoque (Gnocchi Troops), our search here is for comprehending the functioning of the parody - particularly of the Repressive State Apparatus - as a mechanism that allows the displacement of meanings. The groups named Tropas de Nhoque create scenical performances using clown noses, cardboard shields (with the inscription $N H O Q U E$ ) and toy weapons, among other artifacts, satirizing the violent operations of the military police shock troops during confrontations with demonstrators. The analyzed episodes occurred in the streets of Rio de Janeiro and Porto Alegre, in July and September of 2013.

Keywords: Protests; Parody; Tactical performance; Clown; Tropa de Nhoque.

\section{Introduçáo}

\footnotetext{
${ }^{1}$ Bolsista CNPq-Brasil.

${ }^{2}$ Bolsista CNPq-Brasil.
} 
Porto Alegre, ano de 2013. Assistimos às celebraçóes do dia da independência. Nosso olhar é fisgado por dezenas de manifestantes que correm pelas ruas. Alguns levantam bandeiras com siglas que nos remetem a lutas e reivindicaçôes ${ }^{3}$. Outros erguem bandeiras negras, sem inscriçôes. Palavras de ordem são entoadas a todo momento: "Espancar trabalhador/ para ter o que comer/ que vergonha/ que vergonha/ deve ser", "Tortura/ assassinato/ não acabou 64", "Não acabou/ tem que acabar/ eu quero o fim da brigada militar" e "Recua/ polícia/ recua/ É o poder popular que tá na rua". A poucos metros da concentração de manifestantes, encontram-se militares enfileirados com o tradicional uniforme verde-oliva, portando cassetetes, capacetes e escudos, estes com a inscrição garrafal "exército" e o brasão da instituição. Alguns passos atrás, há outra fileira de militares, uniformizados, porém sem capacetes e escudos. Em outro ângulo, comparecem soldados montados a cavalo deslocando-se pela rua. De outro lado ainda, algumas pessoas encontram-se paradas, observando o espetáculo dos desfiles militares de 7 de setembro e dos protestos. Um episódio radicalmente equívoco, que nos convoca à leitura das tensóes e disputas discursivas constitutivas de nosso cenário social.

Para esta leitura a que somos convocados, propomos uma escuta sustentada por certas memórias da prática artística palhacesca. Nossas discussôes trabalham a paródia, como funcionamento produtivo, em protestos atravessados por performances cênicas, em particular, as encenadas pelas Tropas de Nhoque. São assim nomeadas as intervençôes artísticas constituídas por sujeitos que, parodiando as operaçóes dos Aparelhos Repressivos de Estado, criticam seu investimento violento contra civis em manifestaçôes de rua. Entre outras demandas, a própria desmilitarização das polícias no Brasil é recorrente. Versóes da Tropa de Nhoque foram levadas a manifestaçôes em Porto Alegre ${ }^{4}$, Rio de Janeiro, Fortaleza e São Paulo entre 2013 e 2016. A palhaçaria como prática artística, metonimizada pelo nariz de palhaço, compareceu em grande parte dessas açóes.

\footnotetext{
${ }^{3}$ MRS (Movimento Revolucionário Socialista) e CPERS (Sindicato representante de professores e funcionários de escolas da rede estadual do Rio Grande do Sul) são duas das siglas visíveis.

${ }^{4}$ Neste trabalho, o material de análise constituído em Porto Alegre data de 7 de setembro de 2013, mas ressaltamos que açóes das Tropas de Nhoque na capital gaúcha ocorreram em outras oportunidades, como a do dia 5 de julho do mesmo ano, em que seus integrantes satirizavam o protesto dos soldados da Brigada Militar por melhores salários. Disponível em: <https://www. terra.com.br/noticias/brasil/cidades/rs-somos-ordeiros-avisam-pms-em-protesto-por-melhores-salarios,857d8edbf30bf310VgnVCM10000098cceb0aRCRD.html>. Acesso em: 30 jun. 2019.
} 
Como foco de nossa análise, definimos dois vídeos que documentam manifestaçôes de rua ocorridas no Rio de Janeiro e em Porto Alegre, em julho e setembro de 2013, cuja circulação deu-se no YouTube. A esses vídeos relacionamos uma fotografia, que nos apresenta uma cena do Rio de Janeiro de 1968, e um outro vídeo sobre manifestações em Sáo Paulo em 2011. Recortamos diferentes açóes das Tropas de Nhoque como ponto de ancoragem de nossa análise, considerando sua discursividade de protesto, que ressignifica as forças repressivas de Estado pela sua parodização, e abre, em nosso entender, possibilidades de deslocamento no espaço dos confrontos sociais. A questấo que conduz este texto, ancorada na Análise do Discurso Materialista, é: como as intervençôes das Tropas de Nhoque deslocam sentidos de polícia/ exército/ brigada militar, fortemente estabilizados em nossa formação social?

\section{Não é um(a memória de) palhaço qualquer}

No Brasil, há efeitos de sentido regulares do uso do nariz de palhaço por sujeitos em manifestaçóes de rua, como, por exemplo, o de denúncia por terem sido ludibriados, enganados: "(Não) sou palhaço", denegam. Por outro lado, também há sujeitos significando-se palhaços por meio de açôes provocativas e de deboche, caso dos integrantes das Tropas de Nhoque, o que possibilita a constituiçáo de sentidos outros para o gesto de vestir a máscara palhacesca, em distintos processos de identificação, e coloca em circulação diferentes discursividades - até mesmo antagônicas às primeiras: "Sou palhaço e, como tal, estou aqui protestando".

Variadas memórias constituídas ao longo de séculos, em diversas práticas artísticas nas quais o humor é a tônica, formam os trajetos de sentidos que sustentam o que se conhece por "palhaçaria" atualmente: bobos, bufôes, hotxuás, clovis, humoristas do cinema, augustos, arlequins, cômicos circenses... a lista não tem fim. Assim como são infindáveis os sentidos de palhaço metonimizados pelo nariz vermelho em dada interlocução, seja ela ocorrida numa performance ou objeto artísticos (circo, teatro, filmes etc.), ou aquela que se dá em uma manifestação de rua. $\mathrm{O}$ nariz de palhaço, portanto,

\footnotetext{
${ }^{5}$ Esse termo, conforme Demian Reis (2013, p. 21-22), é usado para designar "uma dramaturgia do palhaço que diz respeito a seu espetáculo e a características particulares de sua forma de atuação". "Se o sufixo 'ria' tem relação com lugar, atelier e oficina - como a alfaiataria do alfaiate, a peixaria do vendedor de peixe e a padaria do padeiro -, entáo, por que não palhaço e palhaçaria?" - questiona o autor. Assim, palhaçaria é considerada, neste artigo, como prática, ato, ofício... artísticos.
} 
é equívoco, possibilitando que os sujeitos que o utilizam sejam significados palhaços de modo contraditório. Apesar disso, pelo funcionamento do efeito ideológico elementar, a filiação de sentidos aparece "apagada", "negada", produzindo a ilusáo de evidência para um sentido único de palhaço, "como se o sentido [de palhaço] surgisse ali mesmo" (ORLANDI, 1996, p. 92).

As açóes das Tropas de Nhoque são sustentadas por memórias da palhaçaria que estão longe de colocar a figura do palhaço como aquela cujo efeito é o de alguém que foi passado para trás ("feito de bobo"), como a de certos circenses, por exemplo, que interpretam esquetes nas quais há, com alguma frequência, uma narrativa de trapaças, burlas e falcatruas. De outro lado, as práticas artísticas filiadas às memórias da bufonaria encontram na criticidade e na zombaria outras formas de produzir sentidos de palhaço. Muito embora possam parecer práticas diametralmente opostas, elas não têm fronteiras determinadas. Quando se veste um nariz de palhaço, esse gesto vem carregado dessas e de tantas outras memórias. Para a análise dos materiais sobre os quais nos empenhamos, delimitamos algumas dessas memórias pensando os efeitos de sentido nas condiçóes de produçáo dos protestos.

\section{Um batalháo de palhaços parodiando um bando de policiais}

Paródia e bufonaria vêm caminhando juntas ao longo de séculos. $\mathrm{O}$ potencial do riso como resultado da paródia, segundo Vanessa Bordin (2017, p. 162), "possui uma estrutura de desmoralização ao zombar do poder, e está intrínseco ao jogo do bufẵo desde sua origem”. Pela paródia, ainda de acordo com a autora, num contexto medieval, ao assumir o papel do rei, invertendo a hierarquia, o bufẫo colocava-se acima do sistema que oprimia a ele próprio e ria desse sistema, ridicularizava-o. Atualmente, não é muito diferente. Seja em suas práticas medievais ou nas atuais, bufôes trata(va)m da dimensão social das relaçóes humanas, denunciando absurdos. Jacques Lecoq (2010, p. 182, grifos nossos) ilustra:

Os bufôes sempre vêm diante do público para representar a sociedade. A partir daí, todos os temas são possíveis: a guerra, a televisão, o Conselho de Ministros ou qualquer outro evento da atualidade, fontes inesgotáveis de inspiração e de interpretação. Às vezes, fantasiam-se de personagens de nossa sociedade: póem um quepe, uma roupa religiosa e se aventuram a representar esses personagens. 
"O ator que parodia também se caracteriza ao vestir a máscara que o assemelha ao seu objeto de paródia, denunciando atos e convicçóes de quem está parodiando" (BORDIN, 2017, p. 165). Nas Tropas de Nhoque, em vez do quepe, há os capacetes e outros tantos objetos que funcionam como essa máscara que torna similares, sem, no entanto, identificar parodiador e objeto de paródia. Nesse trecho, Bordin refere-se a um ator profissional, mas consideramos também que há uma teatralização da resistência política que ocorre indistintamente em protestos, seja por especialistas nas artes performáticas ou manifestantes sem qualquer formação nesse campo. Essa teatralização, cujo efeito é paródico no caso de nosso objeto, é uma resposta simbólica possível. Segundo José Sánchez (2012, p. 306, grifos nossos, tradução nossa):

Não se trata mais de animar teatralmente manifestaçóes, greves ou processos políticos, mas de utilizar a teatralidade como instrumento de denúncia, de encenação de sofrimento, da crueldade e da injustiça. A teatralização da resistência política é uma resposta coerente à espetacularização da política global ${ }^{6}$.

Não é um gesto exclusivo de atores profissionais, por mais que, regularmente, seja engendrado nas práticas teatrais. Como foi o caso de uma das apariçôes da Tropa de Nhoque, em Porto Alegre, em 15 de julho de 20137 , durante uma ocupação popular da Câmara Municipal que durou quase oito dias 8 , na qual foram organizadas oficinas de palhaçaria, coordenadas por uma das lideranças dos coletivos artísticos presentes?.

\footnotetext{
${ }^{6}$ Versão original: "Ya no se trata de animar teatralmente manifestaciones, huelgas o procesos políticos, sino de utilizar la teatralidad como instrumento de denuncia, de escenificación de sufrimiento, la crueldad y la injusticia. La teatralización de la resistencia política es una respuesta coherente a la espectacularización de la política global".

${ }^{7}$ Em 15 de julho de 2013, foi realizada uma performance da Tropa de Nhoque, estruturada durante a ocupação da Câmara Municipal de Porto Alegre. O coletivo se denominava Mascaristas Anarcados. No link a seguir, é possível assistir a um vídeo desse momento: <https://www. facebook.com/waldomiroaugusto/videos/10201550569065626>. Acesso em: 30 jun. 2019.
}

${ }^{8}$ Disponível em: <https://ultimosegundo.ig.com.br/brasil/rs/2013-07-18/manifestantes-deixam-camara-municipal-de-porto-alegre-apos-oito-dias-de-ocupacao.html>. Acesso em: 30 jun. 2019.

9 "Nem todo mundo que tava lá tava pela plenária, muita gente que tava lá, tava pela junção. Mas a junção era politizada. Então eu fiquei muito nessa energia de ficar nos grupos fora, e trabalhando. Tipo, entre meia-noite e as 2 da manhă, a gente tinha uma oficina de palhaço pra 
Anteriormente, ainda naquele mês, outras intervençôes da Tropa de Nhoque já haviam acontecido.

Para Vladmir Propp (1992, p. 84), o funcionamento da paródia, considerada por ele um dos instrumentos mais poderosos de sátira social, está no ato de imitar características exteriores de um fenômeno para "ocultar ou negar o sentido interior daquilo que é submetido à parodizaçáa”. E, com a condição de revelar "a fragilidade interior do que é parodiado" (PROPP, 1992, p. 87), ela se torna cômica. Orlandi (1996, p. 114) retoma o sentido grego de paródia - "canto ao lado de outro" -, para discorrer sobre o que significa "ao lado de outro". A autora afirma que os sujeitos e os sentidos concernidos na paródia "não coincidem” e "jogam entre si” (p. 122), abrindo-se um espaço de indistinção simbólica em que o sujeito "trabalha e é trabalhado por ordens diferentes" (p. 124). "Os pontos de diferença são pontos de deriva [...]. Em que o sujeito se descola de sentidos que o repetem e se desloca por onde o sem-sentido pode fazer sentido" (p. 125), continua a autora.

Interessa-nos, na paródia, esse espaço de jogo entre diferentes formaçóes discursivas, que potencializa o descolamento e se abre para o deslocamento. Temos aí o trabalho do alhures. Ao reatualizar em diferentes formulaçóes, a paródia ressalta a possibilidade do que pode vir a ser de outro modo, ao mesmo tempo chamando o olhar e aguçando a escuta para o que está posto, fazendo com que nos defrontemos com esse mesmo que, muitas vezes, insiste em nos afrontar. A paródia, em seu funcionamento constitutivamente interdiscursivo, permite a atualizaçáo de um discurso anterior, deslocando sentidos entre as fronteiras contraditórias e porosas das formaçóes discursivas. O conflito que produz efeito paródico nas intervençôes das Tropas de Nhoque é trazido à tona por gestos de ridicularização das práticas dos Aparelhos Repressivos de Estado, inscritos na memória discursiva: "um espaço móvel de divisóes, de disjunçôes, de deslocamentos e de retomadas, de conflitos de regularizaçáo [...] Um espaço de desdobramentos, réplicas, polêmicas e contradiscursos" (PÊCHEUX, 1999, p. 56).

fazer a Tropa de Nhoque. A Tropa de Nhoque ia lá incomodar, né. Chegou a mídia, a gente conseguiu impedir que entrasse a polícia, que entrasse as TVs, sem ser na nossa hora. Uma tropa de palhaços, com uns isopor quebrado como escudo, e isso serviu para frear. Entáo isso nos deu uma sensação muito clara de que 'estamos sabendo o que estamos fazendo'. Eu faço aquela entrevista que ficou clássica, dos Mascaristas Anarcados e tal. É uma forma de fazer protesto, é uma nova forma de fazer protesto", diz a artista que liderou o grupo em entrevista a Camila da Silva (2016, p. 101). 
Filipo Figueira (2018, p. 102) busca abordar as paródias "a partir das condiçóes de produção e das estruturas semântico-discursivas dos discursos em relação paródica”. Para o autor, a paródia operaria

na mesma proporção que um simulacro: uma formação discursiva que lê outras formaçóes discursivas e que a ela se opóe; no entanto, não o faz abertamente, expressando diretamente sua diferença, mas simula um de seus semas, por vezes recorrendo à cópia estrutural, reformulando-o, seja por oposição, inversão, ou apenas em uma nova direção de sentido (FIGUEIRA, 2018, p. 111).

Nesse processo de retomadas, reatualizações e reformulaçóes produzidas pela paródia, nosso investimento faz-se sobre os elementos colocados em foco pela Tropa de Nhoque.

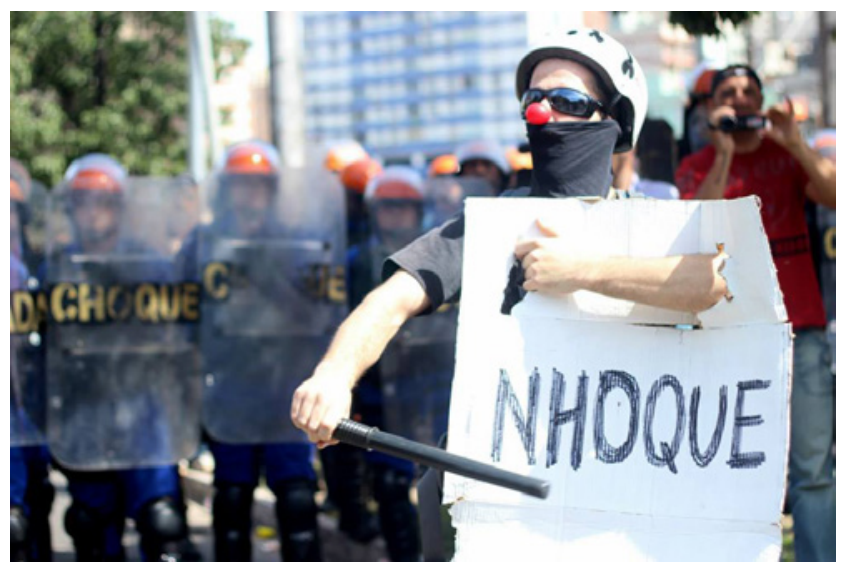

Figura 1: fotografia de protesto durante parada militar e estudantil pelas celebraçóes do 7 de setembro em Porto Alegre.

Fonte: Facebook ${ }^{\mathbf{1 0}}$.

Sáo vários os trocadilhos que pavimentam um extenso trecho dos caminhos anedóticos palhacescos, como o estampado na fotografia acima, em que o sujeito com nariz vermelho, tendo a letra $N$ em vez de $C$ em

\footnotetext{
${ }^{10}$ Foto: Dani Berwanger/Arquivo pessoal. Disponível em: <https://www.facebook.com/photo. php?fbid=10200675807079384>. Acesso em: 30 jun. 2019.
} 
seu cartaz-escudo, é capaz de satirizar todo um agrupamento de homens sisudos. Por isso, os gestos do palhaço-soldado acima, na capital gaúcha, quando das celebraçôes oficiais pela data que rememora a independência do País, são aproximados aos de um bufão. Ao imitar, mimetizar, parodiar os gestos da polícia, pondo-se em marcha à frente do batalhão, com um capacete (in)apropriado para o confronto e batendo o cassetete de plástico contra seu cartaz-escudo de papeláo, o palhaço-soldado ironiza e desdenha da instituição. É um bufão representante de uma jocosa associação "paramilitar", munida de piadas e movida pela própria falha da língua, na fissura que a parodização provoca, "em defesa das massas" ${ }^{11}$ Com parte da população em polvorosa nas ruas, em 2013, os palhaços-soldados levam essa prática "ao pé da letra", dando - digamos - uma "rasteira morfológica" na palavra "CHOQUE", compondo um anagrama mal decalcado, o ridículo NHOQUE, que textualiza uma denúncia sobre violentas práticas policiais.

Açóes como as das Tropas de Nhoque seriam denominadas, por Lawrence Bogad (2016), performances táticas. Além de pesquisador e autor de obras sobre performance e artivismo, Bogad foi um dos fundadores e componentes do CIRCA (Clandestine Insurgent Rebel Clown Army), surgido na Inglaterra em 2003, cujas intervençôes muito se assemelham às das Tropas de Nhoque e, provavelmente, serviram de inspiração para esta última. Guardadas as diferenças de constituição e atuação, ambas, para o autor, seriam

exemplos de artistas-ativistas experientes que usam seu ofício como um multiplicador de forças em confrontos com o Estado, corporaçóes empresariais e outros rivais ou adversários. [...] Essas performances são respostas criativas à restrição. $\mathrm{O}$ espaço público nas democracias ocidentais está cada vez mais privatizado e regulado. O protesto convencional foi demarcado por remotas "zonas de liberdade de expressão", parecidas com gaiolas, que são perseguidas com prisôes preventivas, vigilância e infiltração, e prejudicadas pelo peso de seu próprio clichê. Diante desses desafios, os ativistas usam as performances para expressar anseios e reivindicaçóes de modo convincente, impulsionar seus movimentos e desencorajar (ou aumentar o custo político) da violência das autoridades (BOGAD, 2016, p. 14-15, tradução nossa) $)^{12}$.

\footnotetext{
11 "Em defesa das massas" é uma formulação que circulava entre os sujeitos que apoiavam a presença das muitas Tropas de Nhoque em operaçáo pelo Brasil de 2013 em diante.

${ }^{12}$ Versão original: "examples of savvy artist-activists using their craft as a force multiplier in confrontations with the state, corporations, and other rivals or opponents. [...] These performances are creative responses to restriction. Public space in Western democracies is increasingly privatized and regulated. Conventional protest has been hemmed in with remote, cage-like
} 
Em suas performances táticas, a Tropa de Nhoque movimenta os sentidos e provoca o riso que desorganiza o funcionamento do político: a violência travestida tem os seus contornos borrados e seu campo semântico invadido. Tropa de choque? Para quê? Contra quem? A deriva de Choque para Nhoque radicaliza o jogo parafrástico e faz com que a associação pelo significante dê visibilidade ao frágil "universo logicamente estabilizado" (PÊCHEUX, 1990) da segurança e da ordem, que opera pela violência. Ataque e defesa ficam embaralhados no espaço da indistinçáo. O escudo de papelâo, que não serve para defender quem o porta, chama a atenção para o quão indefesos sáo todos os que podem ser atacados pela tropa de choque. Também o cassetete de plástico, o capacete de ciclista, o nariz, que metaforiza a possibilidade do riso em meio à truculência policial, materializam parafrasticamente a fragilidade da divisa entre atacar/ ser atacado/ defender/ defender-se. A tropa de choque ataca para defender o quê? O preenchimento das lacunas deste enunciado vai apontar para diferentes posiçóes.

Suzy Lagazzi, ao ler $\mathbf{O}$ discurso: estrutura ou acontecimento, de Michel Pêcheux, pontua dois movimentos constitutivos de uma análise discursiva que se configuram diferentemente, não cabendo uma indistinção:

Dando especial relevo à afirmação de Michel Pêcheux (1990, p. 50) de que no trabalho sobre as materialidades discursivas devemos "dar o primado aos gestos de descrição", de tal maneira que descrição e interpretação não sejam tomadas na indistinçấo uma da outra, considero que é ao colocar a estrutura em relação com outras possibilidades estruturais no jogo da história, é ao dar lugar à descrição pelo procedimento parafrástico, que a evidência de um sentido pode ser relativizada e o analista pode dar consequência ao movimento da interpretaçáo para compreendê-lo em seus pré-construídos (LAGAZZI, 2015, p. 177).

A descrição da formulação visual ${ }^{13}$ remete ao apontamento dos elementos linearizados no intradiscurso, procedendo, então, ao exercício parafrástico, que torna possível "colocar a estrutura em relação com outras possibilidades estruturais no jogo da história” (LAGAZZI, 2015, p. 177).

"free speech zones," harassed with preemptive arrest, surveillance, and infiltration, and hampered by the weight of its own cliché. Faced with these challenges, activists use performance to communicate desires and grievances convincingly, to build momentum for their movements, and to discourage (or increase the political price of) violence from authorities".

${ }^{13}$ Suzy Lagazzi propóe uma diferença conceitual entre formulação visual e imagem: "Nessa diferença que estabeleci entre formulação visual e imagem, localizei a formulação visual na relação com o intradiscurso e a imagem na relaçáo com o interdiscurso" (LAGAZZI, 2015, p. 181). 
Esse movimento tensiona a deslinearizaçáo dos elementos constitutivos da formulação visual, que se encontram dispostos sob o efeito de evidência, como se os componentes do fotograma náo pudessem ali estar de outro jeito. O exercício parafrástico, ao pretender recompor a série de possibilidades estruturais que formam uma mesma regiáo de sentidos, tensiona a diferença no mesmo, isto é, a polissemia na paráfrase, viabilizando o gesto de leitura, a interpretação.

\section{Porto Alegre, 7 de setembro de 2013}

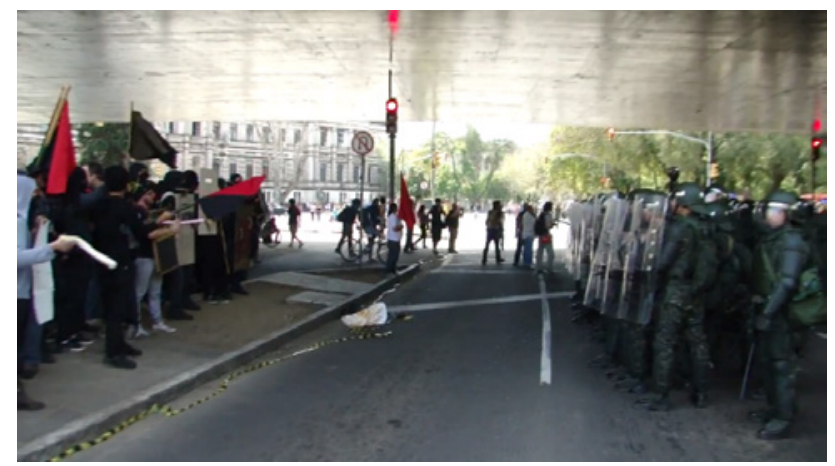

Figura 2: fotograma marcando uma separação entre manifestantes e militares nas ruas. Fonte: YouTube ${ }^{14}$.

Dois lados de uma cena que náo cessa de se atualizar: manifestantes de bandeiras empunhadas, cantando palavras de ordem, e militares de escudos erguidos, em formação. Uma cena prototípica, "concentrando o já-visto e demandando a remissáo do intradiscurso ao interdiscurso para a compreensão dos pré-construídos estabilizado(re)s" (LAGAZZI, 2015, p. 184). O já-visto da disposiçáo dos corpos dos manifestantes e das forças repressivas em protestos inscreve-se no fotograma acima. Soldados, à direita, em silêncio, armados, quase indistintos, detendo o conhecimento especializado sobre o uso da força e sobre as técnicas da morte, significando a violência armada. À esquerda, os manifestantes que gritam e levantam bandeiras apresentam-se singularmente vestidos, parodiando a violência e a travestindo, desorganizando seus sentidos.

${ }^{14}$ Disponível em: <https://youtu.be/F_mYjY5fdC0>. Acesso em: 30 jun. 2019. 
As palavras de ordem entoadas dizem dos militares: "Espancar trabalhador/ para ter o que comer/ que vergonha/ que vergonha/ deve ser", "Tortura/ assassinato/ não acabou 64" e "Não acabou/ tem que acabar/ eu quero o fim da brigada militar". A referência direta a 64, à tortura, a assassinatos, a espancamentos, nos protestos de 2013, é recorrente e merece atenção. A memória da ditadura militar, cantada em refrãos, desdobra-se em famílias parafrásticas que possibilitam significar os manifestantes do lugar que dá voz aos trabalhadores espancados, aos torturados e aos assassinados de 64. Do lado de lá, no outro lugar, os militares ficam atualizados de maneira a significar os agentes que espancaram os trabalhadores, os torturadores, os assassinos. A violência da ditadura fica reavivada nos corpos indistintos dos soldados que se enfileiram diante dos manifestantes. A memória de uma oposição, radicalmente estabilizada, atualizada nas ruas.

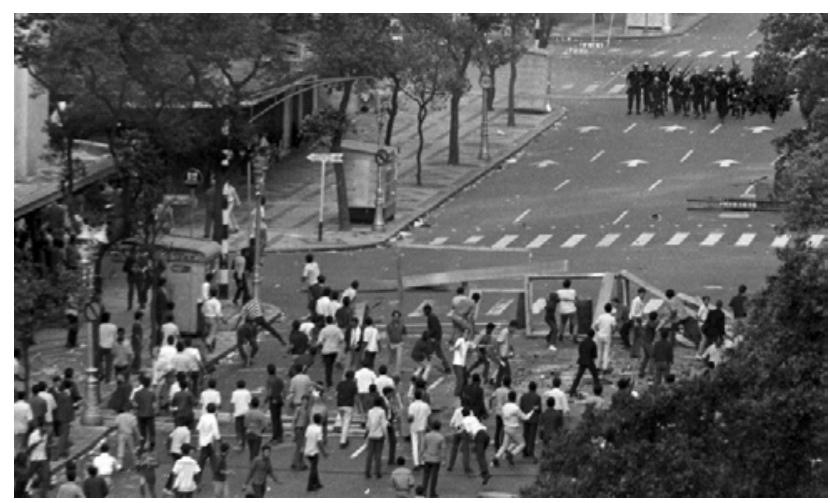

Figura 3: fotografia do episódio intitulado Sexta-feira sangrenta, ocorrido em 1968, no Rio de Janeiro.

Fonte: Campanela/CPDoc JB ${ }^{15}$.

A oposição entre militares e manifestantes, atualizada em 2013, convoca como paráfrase a fotografia acima, formulação visual constituída nas condiçóes de produção de 1968, quando o Brasil encontrava-se na ditadura militar. A rua dividida. Soldados, de arma em punho, marchando em direção à população, que protesta. Alguns dos que protestam não correm, mas reagem, atirando pedras. Fora da imagem, bolinhas de gude foram jogadas no chão para que a tropa montada tombasse de seus cavalos; do alto

15 Disponível em: <http://memorialdademocracia.com.br/publico/thumb/4557/740/440>. Acesso em: 30 jun. 2019. 
dos prédios, pessoas arremessavam objetos, como grampeadores e garrafas de água; os soldados disparavam a esmo. Algo irrompeu no tecido social, fazendo com que a população reagisse ao vandalismo das forças militares:

\begin{abstract}
Na manhã do dia 21, sexta-feira, nova passeata em protesto contra a repressão paralisa o centro do Rio. Os estudantes reagem às investidas da polícia, enfrentando a cavalaria com rolhas e bolas de gude, que fazem os cavalos tombar. A população apoiou os jovens e também atacou a polícia com pedras. Do alto dos prédios, objetos foram atirados sobre os soldados. A polícia reagiu com tiros. Bombas de gás lacrimogêneo foram lançadas de helicópteros. Durante o fim da manhã e toda a tarde, o conflito se espalhou por uma extensa área do centro (Memorial da Democracia).
\end{abstract}

1964 e 1968 trazem marcados os sentidos da violência policial estatal ditatorial que percorreu o regime defendido pelos militares. O fotograma da Sexta-feira sangrenta não deixa dúvidas quanto a esses sentidos.

O funcionamento da paródia na manifestação de Porto Alegre de 7 de setembro de 2013 afasta a Sexta-feira sangrenta de 68. Quando analisada na imbricação entre as materialidades significantes visual, verbal e musical, a manifestação de 2013 traz-nos a contradição pela paródia. A memória dos trabalhadores espancados e das pessoas assassinadas e perseguidas na ditadura militar, atualizada pelos refráos entoados, ecoa pelos versos, mas náo se realiza nos corpos em manifestação. Os militares, em formação, com escudos e armas, náo reagem contra os outros corpos. Os manifestantes cantam e empunham bandeiras, mas também não investem contra os soldados. A dissimetria entre as forças é grande, afinal, à direita, há o aparelho equipado e especializado em matar. Mas a paródia está em funcionamento. A tensão constitutiva dos lugares dissimétricos, que outrora tomaram movimento, fica barrada.

A (o)posição dos corpos na formulação visual de 68 imobilizava os sentidos. Aos corpos, era dado o lugar que deveriam ocupar: enfileirados, com escudos na máo por um lado; desorganizados, em busca de possibilidades de ataque contra a força monumental que se aproximava por outro. A evidência das disposiçóes náo era questionada no antagonismo produzido nas ruas. Nas formulaçôes visuais da manifestação de 2013, o equívoco fazse presente: 


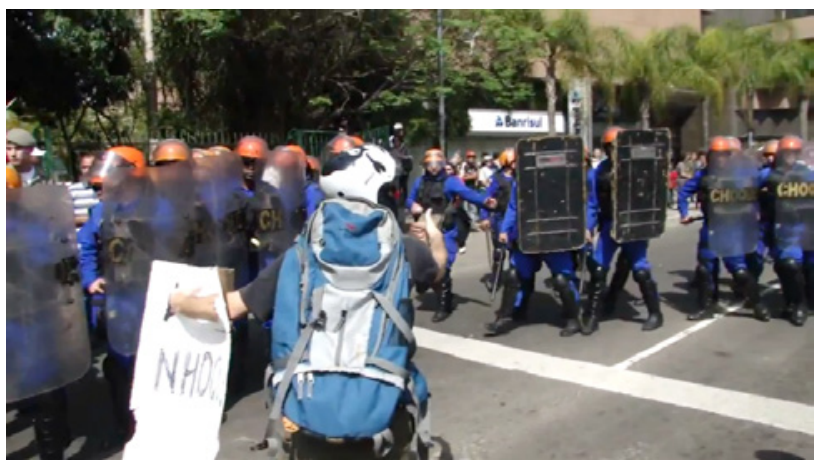

Figura 4: palhaço-soldado e militares organizam a tropa. Fonte: YouTube ${ }^{16}$.

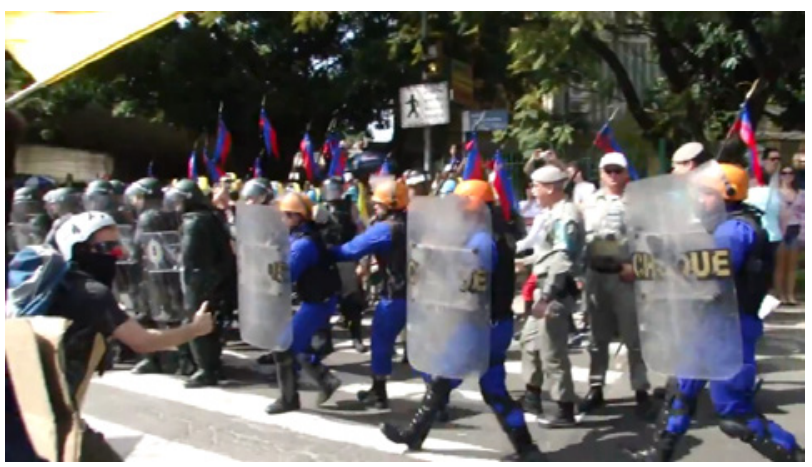

Figura 5: Tropa de Nhoque e tropa de choque em formação. Fonte: YouTube ${ }^{17}$.

O nosso já conhecido palhaço-soldado, representante da Tropa de Nhoque, irrompe em meio à tropa de choque nos fotogramas acima. Os escudos, em contradição, trazem as inscrições Exército, Brigada, Choque e... Nhoque. O palhaço-soldado, sendo o negativo dos militares, um manifestante com um escudo de papelão, um capacete de bicicleta e um nariz vermelho de palhaço, explicita a brutal diferença de poderes entre o aparelho repressivo e aqueles que protestam. $\mathrm{O}$ gesto de organizaçáo dos soldados encontra o

\footnotetext{
${ }^{16}$ Disponível em: <https://youtu.be/F_mYjY5fdC0>. Acesso em: 30 jun. 2019.

${ }^{17}$ Disponível em: <https://youtu.be/F_mYjY5fdC0>. Acesso em: 30 jun. 2019.
} 
mesmo gesto praticado por um militar. A idiotia do movimento dos corpos militares é marcada pelo palhaço da Tropa de Nhoque, ressaltando o caráter de espetáculo daquele ritual repressivo. A disposição dos soldados significa, equivocamente, a ridícula brutalidade, completamente fora de lugar, das forças militares.

A expressão artística, na forma da paródia, como modo de manifestação inscrita no corpo do palhaço-soldado, possibilita deslocar algo do antagonismo posto nas formulaçóes visuais de 68 , mesmo que ainda seja uma forma de protesto constituída a partir de uma posição de sujeito que se contrapóe às forças repressivas. Diferentemente dos outros manifestantes, o palhaço-soldado produz humor na tensão que atravessa o episódio. $\mathrm{O}$ humor toca em sentidos singulares, explicitando o absurdo constitutivo dos rituais militares sobredeterminado pelo imaginário de amor à Pátria e cumprimento do dever jurado às forças armadas. $\mathrm{O}$ gesto do palhaço-soldado aponta para a comicidade e o exagero inscritos nesses movimentos, em relação ao protesto em análise.

\section{Rio de Janeiro, 11 de julho de 2013}

De Porto Alegre ao Rio de Janeiro, voltamos nossos olhares para outra manifestaçáo de rua, ocorrida em 11 de julho, ainda na esteira das Jornadas de Junho de 2013. Intervençóes de mais uma versão da Tropa de Nhoque novamente colocam em cena a paródia, trazendo de volta os singulares escudo, capacete e nariz de palhaço para os protestos na rua. A arte da palhaçaria indumenta os corpos, que parodiam os movimentos das tropas de choque e suas formações. Desta vez, não há paredôes na iminência do confronto. $\mathrm{O}$ vídeo que analisamos a seguir documenta a intervenção de palhaços-soldados, numa versão carioca da Tropa de Nhoque, cuja designação também deriva para Nhoc, Shok, Shot. Confusão de autodesignação? A nãopadronização das inscriçóes nos escudos permite a pergunta: que nome tem essa tropa atrapalhada afinal?

Em algum lugar nas cercanias da Cinelândia, a tropa de choque do Rio de Janeiro deve estar cumprindo sua frágil missão de proteger o patrimônio, garantir a ordem, evitar a baderna e o vandalismo. Neste vídeo, não há encontro do batalhão da polícia militar com a Tropa de Nhoque, exceto pela memória das práticas violentas que já tiveram lugar em tantos outros momentos. Assistimos a uma performance tática específica. Há uma encenação em jogo, produzindo, interdiscursivamente, deslocamentos 
cômicos naquilo que significa choque, violência, brutalidade contra manifestantes, que, na ocasião, em boa parte, eram chamados de vândalos.

O nariz de palhaço é um elo indiscutível entre a versão gaúcha e a carioca da Tropa de Nhoque. No jogo entre o que se mantém e o que se modifica, o nariz ganha novas cores no verde e no azul, as cabeças são suporte náo apenas para o capacete de ciclismo, mas também para capacetes de brinquedo, chapéus de bobo da corte, bonés sob escorredor de macarrão, nas mãos, arminhas esguicham água, seguram um cavalinho de pelúcia, as roupas coloridas ou com estampa de camuflagem alegram os corpos... e os escudos de papeláo reafirmam-se como pastichos humorísticos das tropas de choque.

Enunciados em meio a sons de vaias e risos verbalizam a performance em pequenos atos, durante os quais se alterna o papel do comandante da tropa, que recebe em coro as respostas:

\author{
[vaia] \\ [vaias em coro] \\ Tropa de Nhoque, qual é sua missão? \\ Organizar as massas, começar a confusão. [coro] \\ Tropa de Nhoque, qual é sua missão? \\ Organizar as massas, começar a confusão. [coro] \\ Nhoque vai te pegar. \\ Nhoque vai te pegar. Nhoque vai te pegar. [coro]
}

Rodeados por outros manifestantes, que seguram bandeiras, cartazes e vestem-se com camisetas que dizem de sua filiação sindical ou partidária, os palhaços-soldados vão repetindo, em paródia, o modo como os batalhôes militares atuam em manifestaçôes sociais, seja para dispersar os sujeitos em protesto ou reprimi-los. A repetição de comandos e respostas verbais dá o tom do deboche, que se seguirá por toda a performance planejada pelo grupo, numa variação entre a tentativa de organizar-se como tropa e de tornar, por outro lado, o espaço caótico, "fingindo-se" assustadoramente perigosa (como um bicho-papáo): "Nhoque vai te pegar", enunciam os palhaços-soldados numa jocosa "ameaça" aos manifestantes presentes.

Esse primeiro bloco de enunciados constitutivos da performance são também formas paródicas de um funk que trata da especificidade da atuação do BOpE (Batalhão de Operaçóes Especiais) na capital fluminense, 
colocando esse acrônimo também em relação de sentidos com CHOQUE e NHOQUE pelo modo como a tropa de elite carioca atua ameaçando nada jocosamente - determinados sujeitos no espaço urbano: as memórias de intimidação, pavor e medo atualizam-se. A música $B O p E$ Vai te Pegarr ${ }^{18}$ faz parte do disco Bonde do Caveirão ${ }^{19}$, lançado em 2006 em resposta aos "proibidōes"20: "[...] Homens de Preto, qual é sua missão?/ Entrar pela favela e deixar corpos no chão!/ Homens de Preto, que é que você faz?/ Eu faço coisas que assusta o Satanás!/ BOpE vai te pegar! (Pega daqui, pega de lá)/ BOpE vai te pegar! (Pega daqui, pega de lá) [...]”.
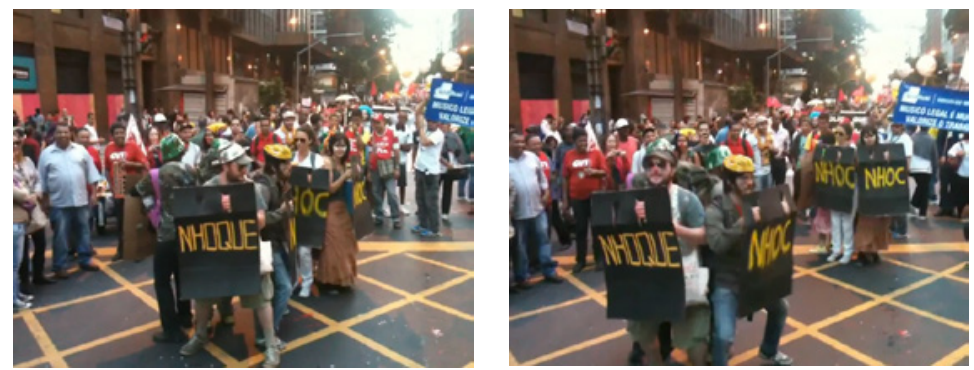

Figuras 6 e 7: Tropa de Nhoque parodiando a formação das tropas de choque cariocas: "faz quadradinho de oito".

Fonte: YouTube ${ }^{21}$.

Formação: quadradinho!

\footnotetext{
${ }^{18}$ Disponível em: <https://www.letras.mus.br/tropa-de-elite/1098146>. Acesso em: 30 jun. 2019.

${ }^{19}$ Caveirão é o apelido dado pela populaçáo ao veículo utilizado pelos soldados do $\mathrm{BOpE} \mathrm{em}$ suas operaçôes. Ao caderno Cotidiano, da Folha de S. Paulo, uma "moradora do largo do Bulufa, no Complexo do Alemão (zona norte), contou que, ao chegar de uma festa de aniversário com seu filho de 17 anos, presenciou uma operaçáo policial com o Caveirão e ficou horrorizada. De acordo com ela, ocorria um baile funk na favela e, ao entrar na comunidade, os PMs colocaram o CD no alto-falante do Caveirão, o que provocou pânico nos moradores. 'Foi uma correria e os bares, que, por causa do baile, ainda permaneciam abertos, fecharam as portas às pressas"” (SILVA, 2006).
}

${ }^{20}$ São como ficaram conhecidos os funks tematizados, por exemplo, pelo tráfico de drogas e que ganhou notoriedades nos anos 1990. Sua circulação era e ainda é clandestina. Em 2017, grupos conservadores chegaram a demandar, por representação legislativa, sua criminalização. Disponível em: <https://veja.abril.com.br/revista-veja/proibindo-os-proibidoes>. Acesso em: 30 jun. 2019.

${ }^{21}$ Disponível em: <https://youtu.be/laNPZwujfao>. Acesso em: 30 jun. 2019. 


\section{Vamos lá? Quadrado!}

Cada um no seu quadrado. Cada um no seu quadrado. [coro repete]

Faz quadradinho de oito. Faz quadradinho de oito.

Faz quadradinho de oito. Faz quadradinho de oito. [coro repete]

Os fotogramas acima nos mostram a Tropa de Nhoque bem "equipada" e ensaiada nos passinhos. Um dos palhaços-soldados, fazendo o comandante da vez, ordena que a tropa esteja em formação "quadradinho", ao que prontamente oito integrantes juntam-se no centro da cena, num grande quadrado. Na sequência, cantando em coro "cada um no seu quadrado", o grupo reparte-se ao meio, formando dois quadrados com quatro integrantes cada. Até que, ainda em coro, vão cantando e dançando um trecho da letra de funk Quadradinho de Oito, criada pelo Bonde das Maravilhas, cujo clímax é o imperativo: "faz quadradinho de oito". Palhaços-soldados e demais manifestantes não se contêm: o riso irrompe naquele espetáculo. A zombaria afrouxa a tensão momentânea daquele contexto em que, a qualquer instante, a tropa de choque pode aparecer para "restabelecer a ordem".
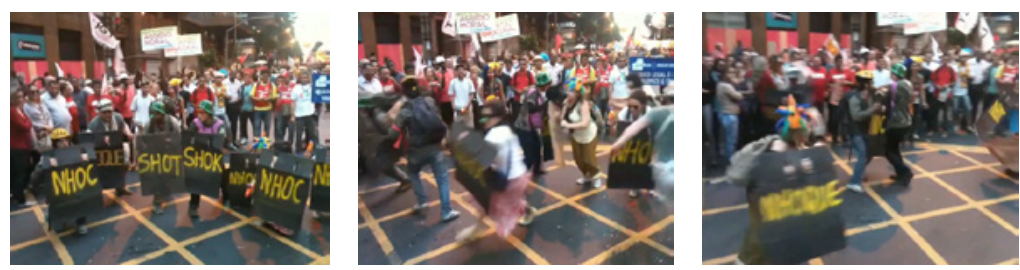

Figuras 8-10: Sequência de fotogramas do momento em que Tropa de Nhoque é ordenada a "restabelecer a ordem".

Fonte: YouTube ${ }^{22}$.

Atenção! Tropa, restabelecer a ordem!

[gritaria, risos]

Tropa, descansar, porra!

[aplausos, assovios dos manifestantes ao redor]

Tá rindo do quê? Tá rindo do quê, seus baderneiros? Seus baderneiros! Fogo nos vândalos!

Vândalos!

\footnotetext{
${ }^{22}$ Disponível em: <https://youtu.be/laNPZwujfao>. Acesso em: 30 jun. 2019.
} 
Depois da "desordem" trazida pela formação do "quadradinho de oito", é chegada a hora de recuperar a organização da tropa. Sob o comando de restabelecimento, o que de fato acontece é um corre-corre anárquico de palhaços-soldados, trombando-se uns nos outros, rindo e gerando gritaria. O efeito é de desgoverno, do qual se ri. Aqueles que se supóem organizar o espaço público vieram para desordená-lo. Assovios, risadas e aplausos dos manifestantes atestam o endosso à desordem. A paródia cumpre seu papel vital de desestabilizar a memória da violência, da ordem que reprime e coage.
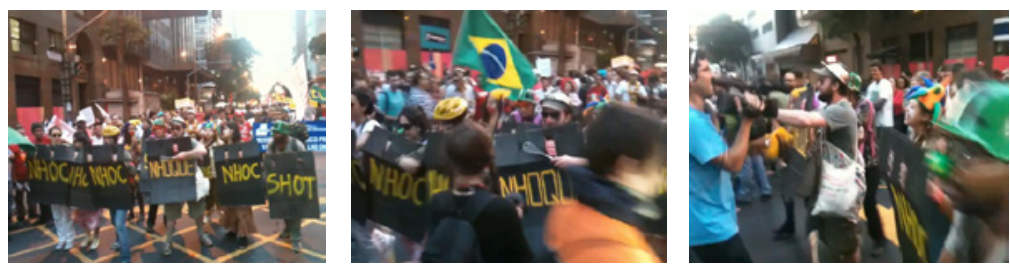

Figuras 11-13: "Nhoc, nhoc, nhoc...", os palhaços-soldados seguem em frente produzindo essas onomatopeias, batendo em seus escudos, avançando, jocosamente, sobre os manifestantes presentes.

Fonte: YouTube ${ }^{23}$.

\begin{abstract}
Organizar as massas!
Tropa de Nhoque...

... qual é sua missão? Organizar as massas e começar a confusão. Tropa de Nhoque, qual é sua missão? Organizar as massas e começar a confusão. Nhoc, nhoc, nhoc...

[risos, aplausos dos manifestantes ao redor]
\end{abstract}

A tropa de palhaços-soldados reordena-se sob o comando de "organizar as massas" proferido pelo comandante. Forma-se o paredão de choque (shot, shok, nhoc). Batendo utensílios de cozinha ou os próprios braços nos escudos, produzindo um batuque "medonho", e embalados pelo cântico que iniciou a performance ("Tropa de Nhoque, qual é sua missão? Organizar as massas e começar a confusão"), os soldados palhaços avançam sobre quem quer que esteja à frente da tropa - manifestantes ou profissionais de imprensa, todos são 'massa' e indistinção. Nhoc!!! $\mathrm{O}$ enunciado traz, concomitantemente, o

${ }^{23}$ Disponível em: <https://youtu.be/laNPZwujfao>. Acesso em: 30 jun. 2019. 
nome da performance tática apresentada (Tropa de Nhoc), e o nome do prato feito com batatas, farinha de trigo e molho (gnocchi). Em onomatopeia, as mordidas devoram a população - nhac > nhoc. "Nhoc, nhoc, nhoc"... os palhaços-soldados vão enunciando, repetindo cadenciadamente, a cada passo à frente.

Diante do ato final da performance da Tropa de Nhoque, no Rio de Janeiro, fica difícil não irromper na memória imagens de tantas outras tropas militares avançando sobre a massa (da população) em incontáveis protestos, como nos mostra a sequência de fotogramas abaixo:
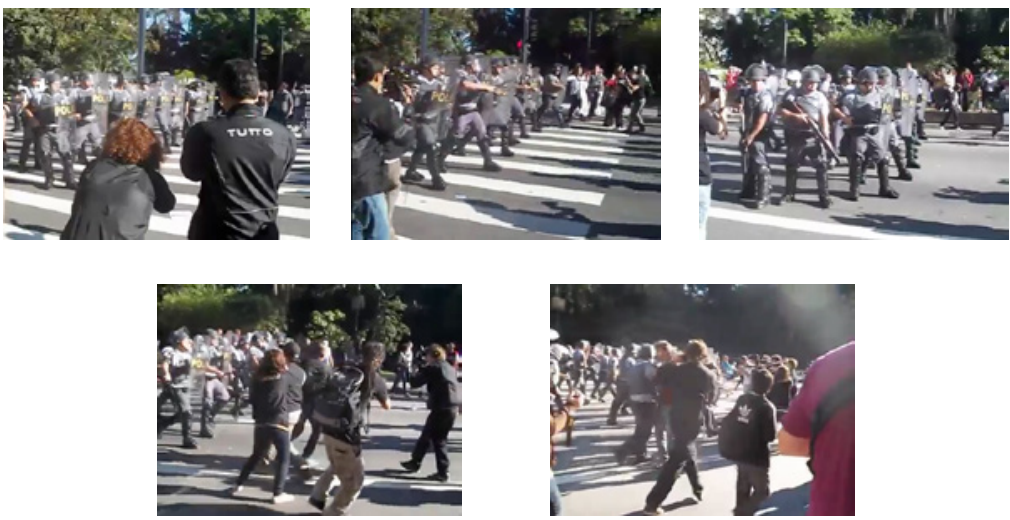

Figuras 14-18: Polícia Militar de São Paulo avança sobre manifestantes e jornalistas durante Marcha da Maconha, em 25 de maio de 2011, na Avenida Paulista.

Fonte: YouTube ${ }^{24}$.

No centro da capital paulista, quando da Marcha da Maconha de 2011, a polícia militar forma o paredão tático para dispersar os manifestantes. As posturas e os movimentos servem de base para a paródia que a Tropa de Nhoque produz. Uma imagem que já se viu? Sim, um jávisto às avessas. Lateralização, pausa, avanço com batuque de cassetetes nos escudos, pausa, formação em grupo ("faz quadradinho de oito"?), pausa, avanço com batuque... Repetição. A imagem repete-se, atualiza-se. Gestos que, interpretados na posiçáo do palhaço-soldado, viram alvos de chacota, ridiculez. Entre a Tropa de Nhoque do Rio de Janeiro em 2013 e a tropa de choque de Sáo Paulo em 2011, sentidos de polícia, exército, forças armadas deslocam-se e produzem como efeito uma semelhante palhaçada. Em relação paródica, o sujeito é capturado no riso. "Descobre-se" por que rir e como rir

\footnotetext{
${ }^{24}$ Disponível em: <https://youtu.be/z35tLWorbpA>. Acesso em: 30 jun. 2019.
} 
do Aparelho Repressivo de Estado.

\section{Consideraçóes finais}

Ancorados na Análise do Discurso Materialista, no presente trabalho, analisamos o processo de produção de sentidos a partir de "diferentes materialidades significantes em composiçáa”, tal como propóe Lagazzi (2009, 2015, 2017). Tomamos como materiais de análise vídeos e fotografias que documentam manifestaçóes de rua. Recortamos distintas açóes das Tropas de Nhoque como ponto de ancoragem de nossa análise, considerando sua discursividade de protesto, sustentada por memórias da prática artística palhacesca - sendo a bufonaria uma delas - que ressignificam as forças repressivas de Estado pela sua parodização.

A inscrição da paródia nas performances cênicas das Tropas de Nhoque, nos protestos de 2013 - especialmente os analisados aqui, ocorridos em Porto Alegre e no Rio de Janeiro -, tanto marca um deslocamento na imobilidade opositiva entre manifestantes e militares, característica das condiçóes de produção da ditadura militar brasileira, quanto expóe, como já reiteramos, a patética violência das práticas contemporâneas dos batalhōes militares em confronto com aqueles que protestam nas ruas. Nossas análises nos permitiram mostrar que o palhaço-soldado parodia gestos e vestimentas, "armando-se" com escudo de papeláo, capacete de bicicleta e nariz de palhaço, explicitando a desmedida e a ridícula brutalidade empregada pelos Aparelhos Repressivos de Estado. O humor expóe o absurdo dos rituais militares nas ruas, que tem como argumentos o amor à Pátria e o cumprimento ao dever.

Compreendemos que a eficácia simbólica das performances das Tropas de Nhoque é, entre outras coisas, resultante da comicidade que a paródia produz como efeito. Por trás do atrevimento das performances de seus soldados de nariz vermelho, há uma coragem que se apoia na compreensão de que "é politicamente mais caro bater num palhaço" (BOGAD, 2017, $\mathrm{s} / \mathrm{p})^{25}$. Esta afirmação se abre para uma oportuna pergunta: que polícia/ político/ país arcaria com esse custo, afinal?

\section{Referências}

${ }^{25}$ Versão original: "it is politically more costly to club a clown". 
BOGAD, Lawrence. Tactical Performance: The Theory and Practice of Serious Play. New York/London: Routledge, 2016.

Playing in the Key of Clown - Reflections on the Clandestine Insurgent Rebel Clown Army. Fifth Estate, n. 397, 2017. Disponível em: $<$ https://www.fifthestate.org/archive/397-winter-2017/playing-in-the-keyof-clown>. Acesso em: 30 jun. 2019.

BOLOGNESI, Mario F. Palhaços e outros cômicos: do sagrado ao profano. In: BRAGA, Bya; TONEZZI, José. (Orgs). O bufão e suas artes: artesania, disfunção e soberania. Jundiaí: Paco, 2017. p. 88-100.

BORDIN, Vanessa. A loucura reveladora dos bufôes na Idade Média: Triboulet e Brusquet, bobos ilustres. In: BRAGA, Bya; TONEZZI, José. (Orgs). O bufăo e suas artes: artesania, disfunção e soberania. Jundiaí: Paco, 2017. p. 162-183.

FIGUEIRA, Filipo P. Argumentos para uma perspectiva discursiva da paródia a partir da teoria da semântica global. Revista do Seta. XXIII Seminário de Teses em Andamento, IEL/Unicamp, Campinas, v. 0, n. 1, jul. 2018. p. 101-112. Disponível em: <http://revistas.iel.unicamp.br/index.php/seta/article/view/5858> Acesso em: 30 jun. 2019.

LAGAZZI, Suzy. O recorte significante na memória. In: INDURSKY, Freda; LEANDRO-FERREIRA, Maria Cristina; MITTMAM, Solange (Orgs.). O discurso na contemporaneidade: materialidades e fronteiras. São Carlos: Claraluz, 2009, v. 1. p. 67-78.

. Paráfrases da imagem e cenas prototípicas: em torno da memória e do equívoco. In: FLORES, Giovanna; NECKEL, Nádia; GALLO, Solange (Orgs.). Análise de discurso em rede: cultura e mídia. Campinas: Pontes, 2015. p. 177-189.

. Trajetos do Sujeito na Composição Fílmica. In: FLORES, Giovanna; GALLO, Solange; LAGAZZI, Suzy; NECKEL, Nádia; PFEIFFER, Claudia; ZOPPI-FONTANA, Mónica (Orgs.). Análise de discurso em rede: cultura e mídia. 1. ed. Campinas: Pontes, 2017, v. 3. p. 23-39.

LECOQ, Jacques. O corpo poético - uma pedagogia da criaçáo teatral. São Paulo: Editora Senac São Paulo; Edições Sesc SP, 2010.

MEMORIAL DA DEMOCRACIA. 28 pessoas morrem na sexta-feira sangrenta. Disponível em: <http://memorialdademocracia.com.br/card/sexta-feira-sangrenta-28-mortos-nas-ruas $>$. Acesso em: 30 jun. 2019.

ORLANDI, Eni P. Interpretaçáo: autoria, leitura e efeitos do trabalho sim- 
bólico. Campinas: Pontes, 1996.

PÊCHEUX, Michel. O discurso: estrutura ou acontecimento. Campinas: Pontes, 1990.

. Papel da Memória. In: ACHARD, P. [et al.]. Papel da Memória. Campinas: Pontes, 1999. p. 49-57.

PROPP, V. Comicidade e riso. Tradução Aurora Bernardini e Homero de Andrade. São Paulo: Editora Ática, 1992.

REIS, Demian M. Caçadores de risos: o maravilhoso mundo da palhaçaria. Salvador: EDUFBA, 2013.

SÁNCHEZ, José A. Prácticas de lo real en la escena contemporánea. Cidade do México: Paso de Gato, 2012.

SILVA, Camila F. da. Inovaçóes nos repertórios de contestaçáo: o confronto em torno do transporte público em Porto Alegre. Dissertação de Mestrado. Porto Alegre: Universidade Federal do Rio Grande do Sul, 2016. 184 p. Disponível em: <https://www.lume.ufrgs.br/bitstream/handle/10183/143124/000996107.pdf?sequence=1>. Acesso em: 30 jun. 2019. SILVA, Nelson. CD exalta violência de tropa de elite do Rio. Folha de $\mathbf{S}$. Paulo, São Paulo, Cotidiano, versão on-line, 05 de agosto de 2006. Disponível em: <https://www1.folha.uol.com.br/fsp/cotidian/ff0508200626. htm>. Acesso em: 30 jun. 2019. 